\title{
Positive correlation between the North Atlantic Oscillation and violent conflicts in Europe
}

\author{
Harry F. Lee ${ }^{1, *}$, David D. Zhang ${ }^{1}$, Peter Brecke ${ }^{2}$ Jie Fei $^{3}$ \\ ${ }^{1}$ Department of Geography and International Centre for China Development Study, University of Hong Kong, \\ Pokfulam Road, Hong Kong, SAR \\ ${ }^{2}$ Sam Nunn School of International Affairs, Georgia Institute of Technology, Atlanta, Georgia 30332-0610, USA \\ ${ }^{3}$ Institute of Chinese Historical Geography, Fudan University, Shanghai, PR China
}

\begin{abstract}
Violent conflicts were more prevalent in historical Europe during colder periods, caused by food scarcity. Up to now, however, cold periods have not been attributed to planetary-scale atmospheric circulation, and thus no relationship between circulation and violence in Europe has been established. In this study, we took an innovative step in exploring the association between the NAO and violent conflicts in Europe in 1400-1995. Our results show that the NAO was positively correlated with violent conflicts, particularly in southern Europe and the Mediterranean-the region in which an NAO-induced desiccation effect is experienced. Results hold up even with different measures of violent conflict. Nevertheless, the NAO-conflict correlation has weakened since the Industrial Revolution. Our result is the first demonstration that the NAO affected social stability in preindustrial societies. This knowledge is crucial in examining violent conflicts in northwestern Africa, a region affected by the NAO, as well as being highly agricultural.
\end{abstract}

KEY WORDS: Climate change $\cdot \mathrm{NAO} \cdot$ Violent conflicts $\cdot$ Europe

\section{INTRODUCTION}

Huntington (1907) suggested that in historical China, the Mongol conquests of the 13th century and Manchu conquests of the 17th century were primarily triggered by climate change. However, linking climate change to social stability subsequently fell from favor, as it smacked of environmental determinism, and also due to the absence of quantitative evidence. During the early 20th century, some historians ruled out investigating natural phenomena altogether, regarding them as purely coincidental facts unrelated to human history (Pfister 2007).

With the advances in high-resolution paleoclimate reconstructions over the past decade, scholars can now re-examine the correlation between climate change and social stability over long periods of human history using quantitative methods. They have arrived at remarkable findings with respect to the key issue of concern: whether climate change does (rather than can) affect social stability. For China, it has been demonstrated by statistical analysis of a $1000 \mathrm{yr}$ empirical data record that more wars occur in periods of cold climate, and that food scarcity is the reason (Zhang et al. 2005, 2006, 2007b, 2010). In addition, the climate-war association was found to be stronger in some regions than in others, a disparity attributable to regional geographic factors (Zhang et al. 2005, 2007a, 2006). For Europe, Tol \& Wagner (2010) reported similar research findings. Approximately one half of all battles and wars in the world have occurred in Europe, making it the most violent place in human history. About $65 \%$ of all war-related deaths in modern times (i.e. since the Middle Ages) were of Europeans (Eckhardt 1991) ${ }^{1}$. As with histori-

\footnotetext{
1Eckhardt's (1991) statement is based on the absolute number of battles/wars and war-related deaths, but the probability of an individual being killed in violence may be higher in other cultures and other periods (see Pinker 2011)
} 
cal China, Tol \& Wagner (2010) found that wars were more prevalent during colder periods in the past millennium, and that this relationship weakened over time. Recently, Zhang et al. (2011) further proved that temperature change was the ultimate cause of General Crisis in pre-industrial Europe. In short, extant long-term quantitative studies, focusing solely on the role of temperature in explaining social instability, find violent conflicts more prevalent in historical China and Europe during colder periods.

The North Atlantic Oscillation (NAO) is a largescale meridional oscillation of atmospheric mass between the subtropical anticyclone near the Azores and the sub-polar low pressure system near Iceland. Depending on where the balance of atmospheric mass lies, the NAO is either in a 'high' state (mass balance over the Azores, positive NAO) or 'low' state (mass balance over Iceland, negative NAO). This mass balance acts as a pressure corridor influencing the direction, magnitude and speed of westerlies across the Atlantic Ocean from North America to Europe, and thereby winter-time temperatures and the balance of precipitation and evaporation over both continents (Hurrell 1995, Hurrell \& Van Loon 1997).

Recently, Hsiang et al. (2011) emphasized the particular role of El Niño/Southern Oscillation (ENSO) in explaining past spatial and temporal variation in civil conflicts throughout the tropics. Given the influence of the NAO on temperature and other climate variability in Europe, it is plausible that NAO fluctuations might similarly have affected social stability in European history. In this study we investigate the role of the NAO in violent conflict in Europe.

\section{DATA}

\subsection{NAO}

Decadal scale variations in a speleothem-based precipitation proxy from Scotland and a tree-ring based drought proxy from Morocco reflect quasi-regular occurrences of contrasting precipitation regimes from 1049-1995 (Trouet et al. 2009). These proxy records are from locations at the centres of opposing poles of NAO-driven precipitation regimes. Analogous to the instrumental based NAO index, our NAO index was derived from this data, calculated as the difference of the above proxies (Scotland minus Morocco) during this period (Trouet et al. 2009). The index is shown in Fig. 1A. The index can be downloaded from the World Data Center for Paleoclima-
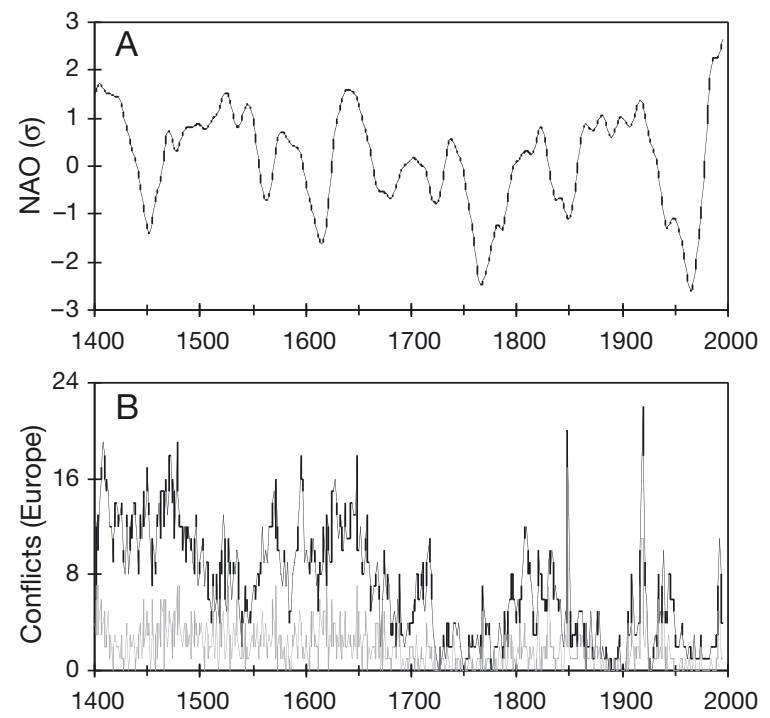

Fig. 1. Comparison of NAO and violent conflicts in Europe. (A) Multi-decadal variability of NAO $(\sigma)$. (B) Number of violent conflicts: Conflict $t_{\text {Preval }}$ (black) and Conflict Onset $_{\text {(grey). }}$ See Section 2 for definition of variables

tology (www.ncdc.noaa.gov/paleo/pubs/trouet2009/ trouet2009.html). We also compared Trouet et al.'s (2009) NAO index with Glueck \& Stockton's (2001) and Cook et al.'s (2002) NAO reconstructions. The correlations were calculated for the 1429-1983 period in which the 3 datasets overlapped. As Trouet et al.'s (2009) series shows the multi-decadal variability of the NAO, to achieve comparability, Glueck \& Stockton's (2001) and Cook et al.'s (2002) NAO reconstructions were smoothed with a 30 yr Butterworth low-pass filter prior to the correlation analysis, with $\mathrm{n}=555$. The associated correlations were 0.437 and 0.548 , respectively. Both of them were strongly significant ( $p<0.01)$, thus confirming the reliability of Trouet et al.'s (2009) dataset.

\subsection{Violent conflicts}

A number of publications contain warfare data for Europe over extended periods (Kohn 1999, Luard 1986, Sorokin 1937). However, the 'Conflict Catalog' (Brecke 1999) is believed to be the most comprehensive dataset for armed conflicts in Europe. The aim of the dataset was to include all recorded violent conflicts that meet Richardson's Magnitude 1.5 or higher criterion (32+ deaths) from 1400 to 1999. The 'Conflict Catalog' is a superset of all other conflict compilations and is the product of the distillation of conflicts found in over 100 different books, articles, and on-line datasets that contain listings of wars. The 
books include encyclopedias or handbooks of military history, compilations of major military battles, academic treatises, historical atlases, and historical chronologies for particular countries or regions. The 'Conflict catalog' makes use of data sources in a number of languages other than English, including French, German, Russian, Turkish, Arabic, Chinese, and Japanese. Significant effort went into resolving inconsistencies between different sources with respect to wars where they overlap. This is a much higher number of wars than has been recorded in any other publication $\stackrel{2}{*}$. The violent conflict data used in this study are listed in the Supplement at www.intres.com/articles/suppl/c056p001_supp.pdf.

In the present study, violent conflict was measured in 2 ways, as shown in Fig. 1B. First, we followed the example of Tol \& Wagner (2010) that if the conflict lasted for $>1 \mathrm{yr}$, it was counted as a conflict in every year that it raged (hereafter Conflict $_{\text {Preval }}$ ) (Fig. 1B, black line). For instance, the Thirty Years War is recorded as a conflict for each year from 1618-1648. Conflict $_{\text {Preval }}$ thus represents the conflation of conflict onset and duration. Secondly, following common practice (e.g. Zhang et al. 2007a), we counted conflicts according to their year of onset (hereafter Conflict $_{\text {Onset }}$ ) (Fig. 1B, grey line). For instance, the Thirty Years War is recorded as a conflict for 1618 only. The associated time series of the 2 conflict measures (collectively referred to hereafter as Conflict) were examined together in the analysis that follows.

\subsection{Control variables}

To control for possible endogenous explanatory variables, to account for unmeasured heterogeneity and to capture temporal fluctuations in the underlying conflict propensity, we employed 3 categories of controls in our longitudinal analyses as follows:

Social development. We included 2 trend breaks to control for conflict suppression effect engendered by social development. The first trend break was the start of the Reformation in 1517, as suggested by Tol \& Wagner (2010). The second trend break was the onset of industrialization, generally agreed to be

\footnotetext{
2In our previous studies (Zhang et al. 2007a, 2011), we use violent conflict data taken from Brecke's (1999) 'Conflict Catalog' to examine the temperature-war relationship for Europe. For their study, Tol \& Wagner (2010) used the war data downloaded from http://warscholar.org/Timeline. $\mathrm{html}$. The violent conflict data in that website is entirely based on Kohn's (1999) 'Dictionary of Wars', which is merely one of the data sources for the 'Conflict Catalog'
}

1800. As described by documentary archives, preindustrial societies were sensitive to wars, which were often driven by deteriorating climate (Brázdil et al. 2005). In addition, the climate-war relationship is found to be much weaker in the modern world than it was in pre-industrial times (Tol \& Wagner 2010). These trend breaks were represented by 2 additive constants, the first one for 1500-1799 (Reform) (Fig. 2A) and the second one for 1800-1995 (Reform \&Indust) (Fig. 2B).

Polity. Over time, Europe became more integrated into larger political entities (from small kingdoms and duchies towards modern nation states and 'empires'). Empires and wars are strongly interrelated, and Eckhardt (1990) demonstrated a correlation between empire growth and war. The growth of empires associates with the growth in warlikeness (Eckhardt 1990). We controlled for that effect by adding the total Empire size in Europe, as documented by Taagepera $(1979,1997)^{\frac{3}{}}$, as an explanatory variable (see Eckhardt 1990) (Fig. 2C). On the other hand, the number of violent conflicts may be positively correlated with the number of states (Hsiang et al. 2011). To prevent that effect from driving any of our results, we also included the total State number in Europe as an explanatory variable (Fig. 2D). The states include both sovereign/independent states and dependent states. Data about the number of states was obtained from Euratlas (www. euratlas.net/history/europe/) and based on the number states at the start of each century (i.e. the number of states in 1400 was used for 1400-1499, the number in 1500 for $1500-1599$, etc.).

Weather. As cold and dry weather could induce economic hardship and contribute to human migration, which subsequently trigger conflict onset (Brázdil et al. 2005), we controlled the short-term impact of weather on conflict risk by adding the inter-annual growth (i.e. the proportional change since the previous year) of temperature (Temperature and Temperature $t_{t-1}$ ) and precipitation (Precipitation and Precipitation $_{t-1}$ ) as explanatory variables (see Buhaug 2010). Our weather variables were derived from Büntgen et al.'s (2011) tree ring-based reconstructions of summer temperature anomalies

\footnotetext{
${ }^{3}$ Empire designates any relatively large sovereign political entity whose components are not sovereign. Taagepera (1979) defined empire size at any given time as the dry land area it controls, at least in the sense of having some undisputed military and taxation prerogatives, determined on the basis of the consensus of historians as expressed through maps in historical atlases and other texts. The area unit used is $\mathrm{Mkm}^{2}\left(1 \mathrm{Mkm}^{2}=0.39\right.$ million square miles $)$
} 

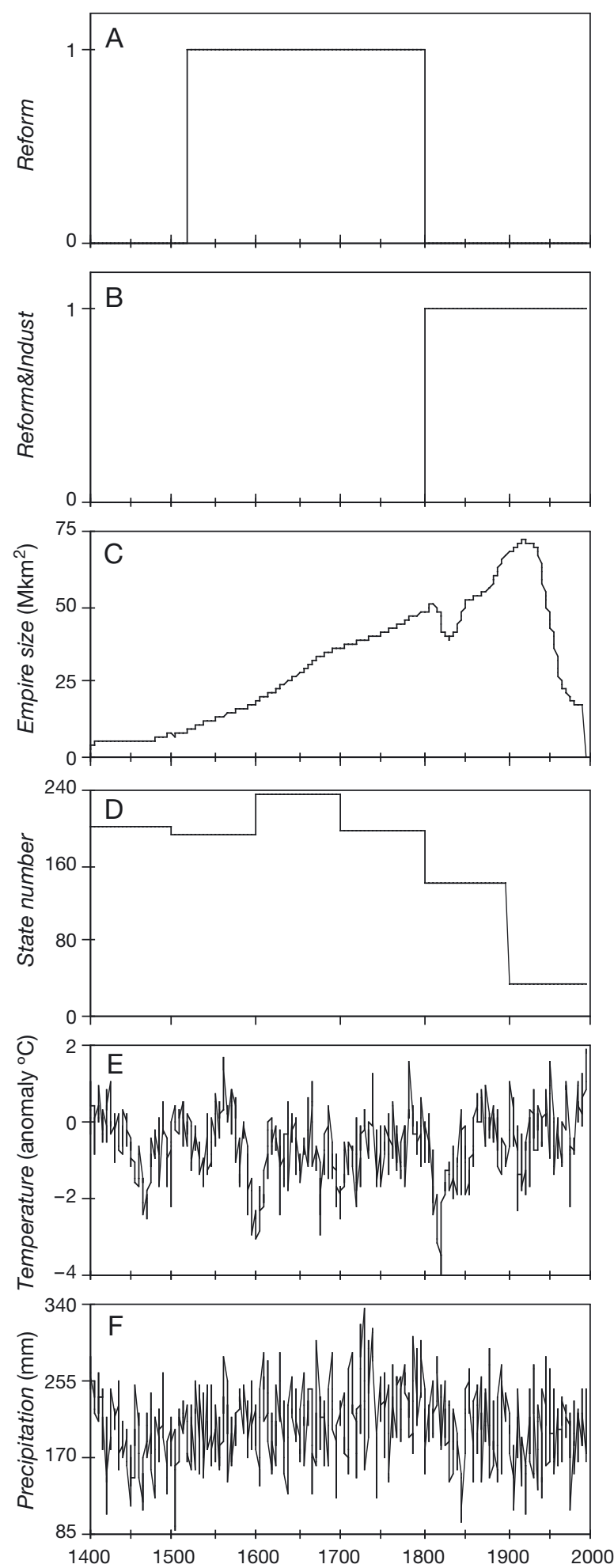

Fig. 2. Comparison of control variables. (A) Dummy for Reformation (Reform): 1500-1799. (B) Dummy for the synthesis of Reformation and industrialization (Reform\&Indust): 1800-1995. (C) Empire size in Europe. (D) State number in Europe. (E) Summer temperature anomaly (Temperature) for Central Europe. (F) Summer precipitation totals (Precipitation) for Central Europe $\left({ }^{\circ} \mathrm{C}\right)$ (Fig. 2E) and summer precipitation totals $(\mathrm{mm})$ (Fig. 2F) for Central Europe, covering northeastern France, northeastern Germany and southeastern Germany.

Our study period was determined as the period 1400-1995, using the entire span of our available data. Multiple regression was employed to quantitatively examine the NAO-Conflict relationship and the relation between Conflict and the control variables. The minimum level of significance was chosen to be 0.1 .

\section{RESULTS}

Table 1 show the results from a number of regression models. In the first model (Models 1 and 1a), we regressed our annual violent conflict time series on $N A O$ and detected a significant increase in Conflict $_{\text {Preval }}(1.149, \mathrm{p}<0.01)$ and Conflict Onset $(0.308$, $\mathrm{p}<0.01$ ) associated with higher $N A O$ values for the whole of Europe. In Models 2-7 and 2a-7a, we regressed our conflict time series on various categories of control variables (i.e. social development, polity and weather, see Section 2.3) individually and in combination with NAO. The NAO effect on Conflict $_{\text {Preval }}$ and Conflict Onset $_{\text {was robust to the inclusion }}$ of the control variables in the regressions. In Models 8 and $8 \mathrm{a}$, we included $N A O$ and all of the control variables. NAO still displayed significant and substantive effect on Conflict Preval $_{\text {( }}(0.701, \mathrm{p}<0.01)$ / Conflict $_{\text {Onset }}(0.208, \mathrm{p}<0.01)^{\underline{4}}$.

We evaluated the sensitivity of the positive NAOConflict correlation by altering the sample of years used in Models 8 and 8a. The tested time spans include 1450-1995 (Models 9 and 9a), 1500-1995 (Models 10 and 10a), 1550-1995 (Models 11 and 11a) and 1600-1995 (Models 12 and 12a) (Table 2). With all of the controls pooled, we found the correlation between NAO and violent conflicts (both Conflict preval and Conflict $_{\text {Onset }}$ ) positively significant across the different time spans. This indicates that our main results were neither driven by the choice of period nor affected by sampling bias.

\footnotetext{
${ }^{4}$ Our control variable Empire size was negatively correlated with Conflict $_{\text {Preval, }}$ which contradicts Eckhardt (1990). One possible explanation is that we focused on the frequency of warfare, while Eckhardt (1990) emphasized the destructiveness of warfare. With the growth of empires, this would make the number of conflicts fewer but possibly bigger as time progresses. Both deaths per population and deaths per war increased between the 15th and 20th centuries (Eckhardt 1991)
} 


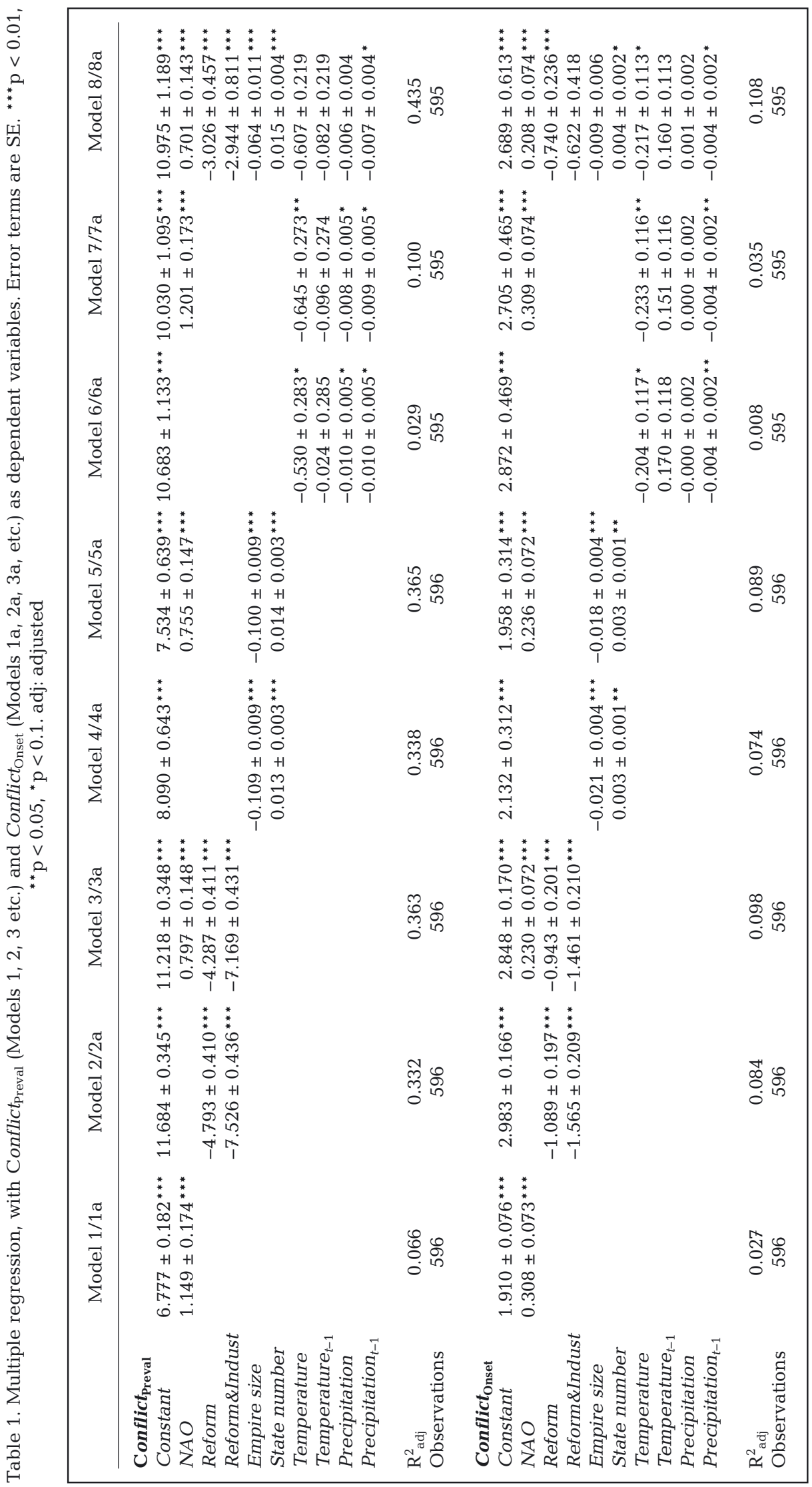




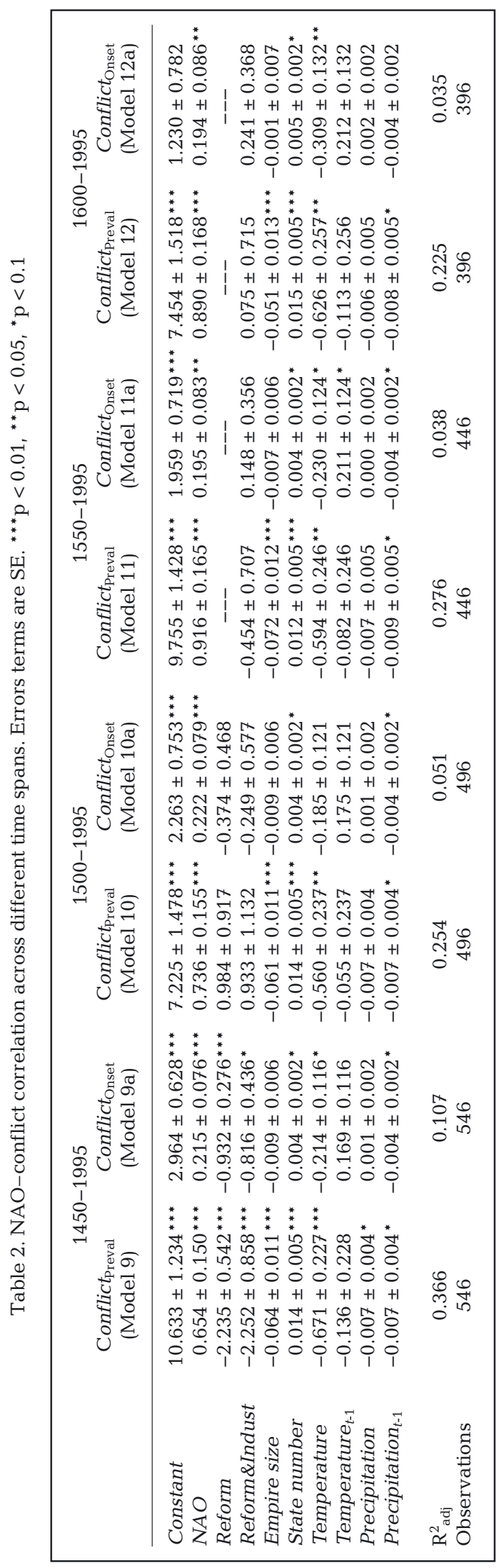

In Models 13 and 13a, we added the number of violent conflicts in the previous $2 \mathrm{yr}$ (Conflict $t_{t-1}$ and Conflict $_{t-2}$ ) as explanatory variables to control for autocorrelated errors (Tol \& Wagner 2010), as recent violence may affect the likelihood of a new conflict breaking out (Buhaug 2010). With this correction for autocorrelation, although the NAO effect on violent conflicts was estimated to be weaker, it still had a statistically significant effect on both Conflict Preval $_{\text {}}$ (0.164, p < 0.1) and Conflict Onset $(0.135, \mathrm{p}<0.1)$ in the expected direction.

Because environmental changes may vary strongly across different locations, patching data from different localities may result in biased and potentially wrong results (Brázdil et al. 2005). Therefore, we further took into account the regional variation of NAOinduced environmental changes across the European continent in our data analysis. During a high NAO winter, the axis of maximum moisture transport shifts to a more southwest-to-northeast orientation across the Atlantic and extends much farther to the north and east onto northern Europe and Scandinavia (Hurrell \& Van Loon 1997). A significant reduction of the total atmospheric moisture transport occurs over southern Europe and the entire Mediterranean sector (Hurrell \& Van Loon 1997) because of anti-cyclonic circulation and reduced cloud cover (Trigo et al. 2002). Turkey also becomes significantly drier. This is the easternmost limit of the NAO influence on the Mediterranean, which extends from Portugal and Morocco to eastern Turkey (Cullen \& DeMenocal 2000).

The NAO regime over the Mediterranean modulates growing season climate over Europe through controlling winter precipitation that initializes the soil moisture states that subsequently interact with temperature. A positive phase of the NAO tends to generate the possibility of a hot and dry summer (or even heat and drought waves) (Wang et al. 2011). Additionally, as reflected by annual stream flow, the NAO-induced reduction of freshwater supply not only happens in winter, but also lasts for the whole year (Cullen \& DeMenocal 2000). The synthesis of heat stress and water strain during growing season is detrimental to agricultural production.

During a positive NAO phase, the desiccation effect is more significant in southern Europe and the Mediterranean, whereas the desiccation effect in northern Europe and Scandinavia is smaller and less consistent. To capture this, we partitioned Europe into 2 regions based on how coupled their climates are to the NAO (Fig. 3), namely Desiccated Europe (Models 14 and 14a; Table 3) and Non-desiccated Europe (Models 15 and 15a; Table 3). The partition was 


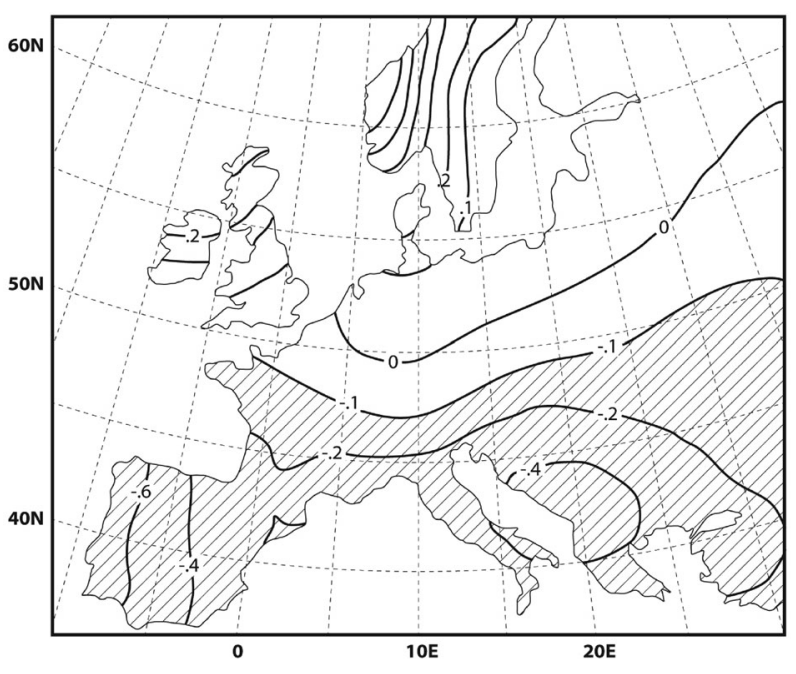

Fig. 3. Location of Desiccated Europe and Non-desiccated Europe. The 2 regions were delineated according to changes in precipitation corresponding to the deviation of the NAO index computed over the winters (DecemberMarch) in 1900-1994 (Hurrell \& Van Loon 1997). Desiccated Europe (hatched) was defined as the area in which precipitation is reduced by $\geq 0.1 \mathrm{~mm} \mathrm{~d}^{-1}$ in response to an increase of 1 unit in the NAO index; the remaining area was delineated as Non-desiccated Europe (unhatched)

based on a precipitation reduction $\left(\geq 0.1 \mathrm{~mm} \mathrm{~d}^{-1}\right)$ corresponding to a one standard deviation increase in the NAO index computed over the winters (December to March) from 1900-1994 (Hurrell \& Van Loon 1997). We regressed our conflict measures for the 2 regions on NAO. To ensure comparability, Models $14,14 \mathrm{a}, 15$ and $15 \mathrm{a}$ retain the same specification as Models 13 and 13a. We detected that NAO was posi- tively correlated with Conflict $_{\text {Preval }}(0.152, \mathrm{p}<0.05)$ and Conflict Onset $(0.103, \mathrm{p}<0.1)$ only for Desiccated Europe (Table 3), the region in Europe in which most of the violent conflicts happened (Fig. 4). This contrasts with Non-desiccated Europe, where no significant NAO-Conflict correlation was found. This implies that the NAO matters only for deterring the violent conflicts in the area under its influence (i.e. southern Europe). Holding all the control variables at their mean, for Conflict Prevall $_{\text {(Conflict }}$ Onset), a one standard deviation increase from mean NAO increased the number of conflicts by 0.049 and 0.022 (0.077 and 0.061) in Desiccated Europe and Nondesiccated Europe, respectively (Table 4). The NAO effect in Desiccated Europe was 123 and 26\% stronger on Conflict Preval $_{\text {and }}$ anflict Onset, $_{\text {respec- }}$ tively, than in Non-desiccated Europe.

Earlier studies about climate-war relationships (Tol \& Wagner 2010, Zhang et al. 2007a, 2011) did not consider the duration of violent conflicts explicitly. We further examined the NAO-induced desiccation effect on violent conflicts for the 2 European regions by taking the duration of violent conflicts into account. We put violent conflicts into 3 categories: $\geq 1 \mathrm{yr}, \geq 3 \mathrm{yr}$ and $\geq 5 \mathrm{yr}$. 'Short' conflicts $(<1 \mathrm{yr})$ were deliberately excluded in the above categorization. Table 4 shows that for Desiccated Europe, positive $N A O$ was significantly associated with more Conflict $_{\text {Preval }} \geq 1 \mathrm{yr}$ (standardized co-efficient $\beta=0.036, \mathrm{p}<$ $0.05), \geq 3 \mathrm{yr}(\beta=0.030, \mathrm{p}<0.05)$ and $\geq 5 \mathrm{yr}(\beta=0.024$, $\mathrm{p}<0.1)$. However, when the measure Conflict $_{\text {Onset }}$ was employed, the positive NAO-conflict association was not replicated. For Non-desiccated Europe, the

Table 3. Regional variation of NAO-Conflict correlation. Error terms are SE. ${ }^{* * *} \mathrm{p}<0.01,{ }^{* *} \mathrm{p}<0.05,{ }^{*} \mathrm{p}<0.1$

\begin{tabular}{|c|c|c|c|c|c|c|}
\hline & \multicolumn{2}{|c|}{ Whole of Europe } & \multicolumn{2}{|c|}{ Desiccated Europe } & \multicolumn{2}{|c|}{ Non-desiccated Europe } \\
\hline & $\begin{array}{l}\text { Conflict }_{\text {Preval }} \\
\text { (Model 13) }\end{array}$ & $\begin{array}{l}\text { Conflict }{ }_{\text {Onset }} \\
\text { (Model 13a) }\end{array}$ & $\begin{array}{l}\text { Conflict }_{\text {Preval }} \\
\text { (Model 14) }\end{array}$ & $\begin{array}{l}\text { Conflict }{ }_{\text {Onset }} \\
\text { (Model 14a) }\end{array}$ & $\begin{array}{l}\text { Conflict }_{\text {Preval }} \\
\text { (Model 15) }\end{array}$ & $\begin{array}{l}\text { Conflict }{ }_{\text {Onset }} \\
\text { (Model 15a) }\end{array}$ \\
\hline Constant & $2.138 \pm 0.779^{* * *}$ & $1.782 \pm 0.610^{* * *}$ & $1.509 \pm 0.575^{* * *}$ & $0.891 \pm 0.455^{*}$ & $1.187 \pm 0.451^{* * *}$ & $1.068 \pm 0.340^{* * *}$ \\
\hline NAO & $0.164 \pm 0.089^{*}$ & $0.135 \pm 0.072^{*}$ & $0.152 \pm 0.069^{* *}$ & $0.103 \pm 0.055^{*}$ & $0.044 \pm 0.050$ & $0.059 \pm 0.040$ \\
\hline Reform & $-0.617 \pm 0.290^{* *}$ & $-0.508 \pm 0.231^{* *}$ & $-0.539 \pm 0.223^{* *}$ & $-0.590 \pm 0.178^{* * *}$ & $-0.235 \pm 0.162$ & $-0.040 \pm 0.126$ \\
\hline Reform\&Indust & $-0.641 \pm 0.499$ & $-0.400 \pm 0.406$ & $-0.412 \pm 0.382$ & $-0.095 \pm 0.309$ & $-0.377 \pm 0.287$ & $-0.332 \pm 0.225$ \\
\hline Empire size & $-0.012 \pm 0.007^{*}$ & $-0.006 \pm 0.006$ & $-0.008 \pm 0.005$ & $-0.005 \pm 0.004$ & $-0.007 \pm 0.004^{*}$ & $-0.002 \pm 0.003$ \\
\hline State number & $0.003 \pm 0.003$ & $0.003 \pm 0.002$ & $0.004 \pm 0.002^{* *}$ & $0.005 \pm 0.002^{* * *}$ & $-0.001 \pm 0.002$ & $-0.001 \pm 0.001$ \\
\hline Temperature & $-0.260 \pm 0.133^{*}$ & $-0.181 \pm 0.109^{*}$ & $-0.161 \pm 0.103$ & $-0.122 \pm 0.083$ & $-0.113 \pm 0.076$ & $-0.068 \pm 0.060$ \\
\hline Temperature $_{t-1}$ & $0.202 \pm 0.133$ & $0.176 \pm 0.109$ & $0.144 \pm 0.102$ & $0.159 \pm 0.083^{*}$ & $0.038 \pm 0.077$ & $0.016 \pm 0.060$ \\
\hline Precipitation & $-0.000 \pm 0.002$ & $0.001 \pm 0.002$ & $0.000 \pm 0.002$ & $0.002 \pm 0.002$ & $0.000 \pm 0.001$ & $-0.001 \pm 0.001$ \\
\hline Precipitation $_{t-1}$ & $-0.002 \pm 0.002$ & $-0.004 \pm 0.002^{*}$ & $-0.002 \pm 0.002$ & $-0.003 \pm 0.002^{*}$ & $-0.000 \pm 0.001$ & $-0.001 \pm 0.001$ \\
\hline Conflict $_{t-1}$ & $0.771 \pm 0.041^{* * *}$ & $0.186 \pm 0.041^{* * *}$ & $0.728 \pm 0.041^{* * *}$ & $* 0.095 \pm 0.041^{* *}$ & $0.785 \pm 0.042^{* * *}$ & $0.244 \pm 0.041^{* * *}$ \\
\hline Conflict $_{t-2}$ & $0.032 \pm 0.041$ & $0.144 \pm 0.041^{* * *}$ & $0.028 \pm 0.041$ & $0.047 \pm 0.041$ & $-0.039 \pm 0.042$ & $0.086 \pm 0.041^{* *}$ \\
\hline $\mathrm{R}_{\text {adj }}^{2}$ & 0.792 & 0.164 & 0.753 & 0.105 & 0.658 & 0.118 \\
\hline Observations & 594 & 594 & 594 & 594 & 594 & 594 \\
\hline
\end{tabular}



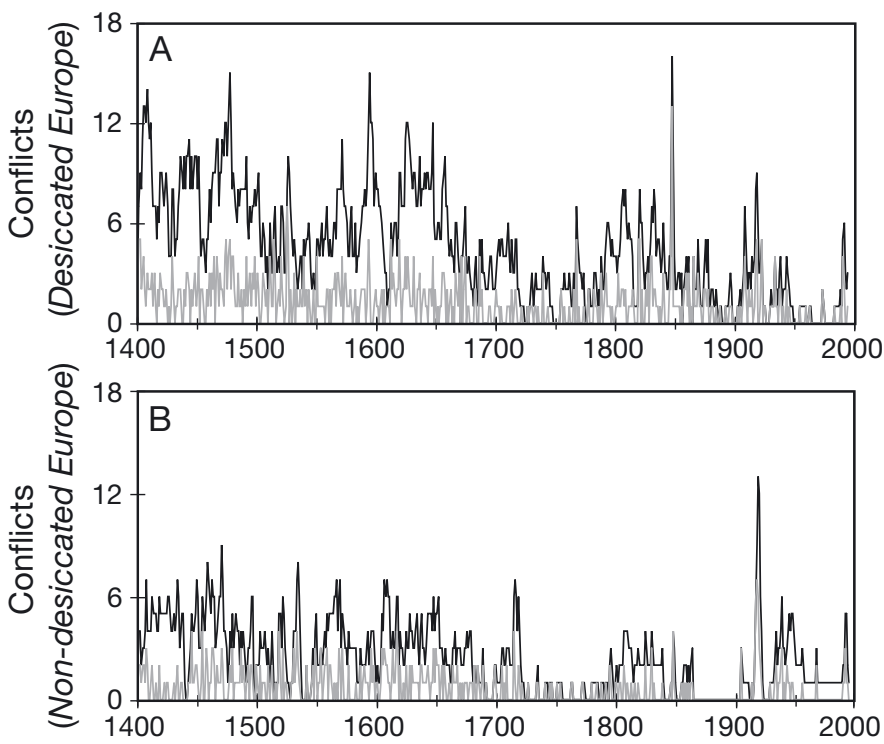

Fig. 4. Comparison of violent conflicts in (A) Desiccated Europe and (B) Non-desiccated Europe: Conflict $t_{\text {Preval }}$ (black line) and Conflict $t_{\text {Onset }}$ (grey line)

correlation between $N A O$ and violent conflicts (both Conflict $_{\text {Preval }}$ and Conflict $_{\text {Onset }}$ ) continued to be absent.

Presumably, individuals and groups competing for resources in order to satisfy their basic needs (i.e. the lower levels of Maslow's (1970) 'Hierarchy of Needs' pyramid) may engage directly in violent conflict without involving state military power (Hendrix \& Salehyan 2012), and this could result in conflicts of short duration. This implies that climate-induced resource shortage is only relevant in triggering the onset of short conflicts. The onset of long conflicts may be attributable to factors other than the NAO. This explains why NAO was significantly correlated with Conflict $_{\text {Onset }}$ (because of the inclusion of short violent conflicts), but not with Conflict $_{\text {Onset }} \geq 1 \mathrm{yr}$, $\geq 3 \mathrm{yr}$ and $\geq 5 \mathrm{yr}$. Nevertheless, constrained food resources and economic difficulties stemming from deteriorating climate could fuel different social contradictions (Zhang et al. 2007a). Once violent conflicts start, their duration could be lengthened by climate-induced resource shortage. This explains why $N A O$ was significantly correlated with both ConflictPreval, and Conflict $t_{\text {Preval }} \geq 1 \mathrm{yr}, \geq 3 \mathrm{yr}$, and $\geq 5 \mathrm{yr}$, re-

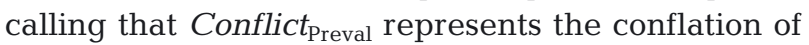
onset and duration of violent conflicts (Section 2.2).

We also examined whether the positive NAOConflict association still holds in industrial period (1800-1995). However, NAO failed to exhibit a significant or substantive effect on violent conflicts (Conflict $_{\text {Preval }}$ or Conflict $_{\text {Onset }}$ ) of any duration, over the whole of Europe, or in Desiccated Europe or Non-desiccated Europe (Table 4). This concurs with Tol \& Wagner's (2010) finding that the climateconflict correlation in Europe has weakened since industrialization.

\section{DISCUSSION AND CONCLUSIONS}

There is a growing body of evidence demonstrating the negative effects of lower temperatures on agricultural productivity and the importance of these fluctuations for social stability in pre-industrial Europe (Tol \& Wagner 2010, Zhang et al. 2007a, 2011). However, we found that the NAO also affected social stability in pre-industrial Europe. Specifically, the NAO was implicated in causing violent conflicts in Desiccated Europe i.e. southern Europe and the Mediterranean), the region in which NAO-induced

Table 4. Changes in annual violent conflict risk in response to NAO. Error terms are SE. ${ }^{* * *} \mathrm{p}<0.01,{ }^{* *} \mathrm{p}<0.05,{ }^{*} \mathrm{p}<0.1$. Values are expressed in standardized coefficient $(\beta)$. A value of 0.049 means that holding all the control variables at their mean, a one standard deviation increase from mean NAO increased the number of conflict incidence by 0.049. For the period 1400-1995, control variables included Reform, Reform\&Indust, Empire size, State number, Temperature, Temperature $t_{t-1}$, Precipitation, Precipitation $_{t-1}$, Conflict $_{t-1}$ and Conflict $_{t-2 i} \mathrm{n}=594$. For the period 1800-1995, control variables included Empire size, State

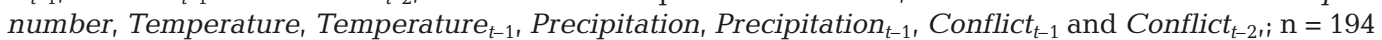

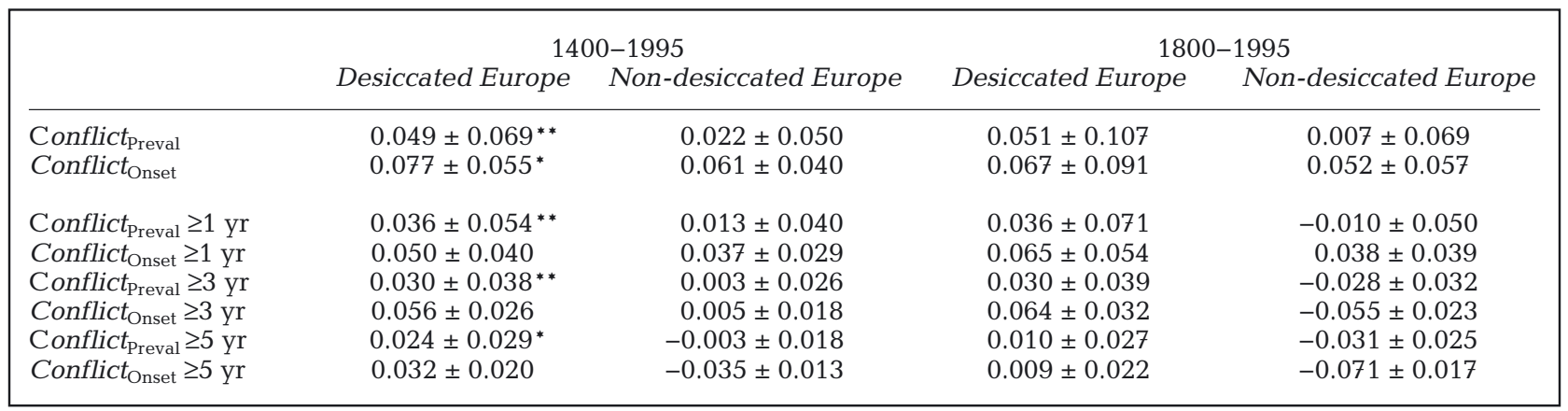


climatic and environmental changes are experienced. This result held regardless of which measure of violent conflicts (i.e. Conflict $t_{\text {Preval }}$ or Conflict $_{\text {Onset }}$ ) was applied. Nevertheless, the NAO-Conflict correlation was weaker in the period since the onset of industrialization.

In the present study, we took a first step towards identifying the positive correlation between the NAO and violent conflicts. Our tentative explanation is that positive NAO could reduce agricultural yields by influencing heat and water supply. Because the vast majority of households in pre-industrial Europe were rural and derived most of their income from agricultural activities (Zhang et al. 2011), such NAO-related yield declines presumably had serious economic consequences for both agricultural households and entire societies that depended heavily on agriculture. Because economic welfare is the single factor most consistently associated with conflict incidence in both cross-country and within-country studies (Burke et al. 2009), it appears likely that variation in agricultural performance is the central mechanism linking positive NAO to violent conflicts in pre-industrial Europe.

The results of comparison of climate variability and human history, however, do not imply any simple causal determination, since other contributing factors, such as socio-cultural stressors, must be considered in the complex interplay of factors leading to the outbreak of conflicts (Büntgen et al. 2011). The impact of climate change varies between different types of conflicts, areas and time periods. Moreover, determinants of war may include a whole range of factors, working at different scales. But, in the present day, climate change and its associated environment change are still detrimental to exposed societies that lack necessary capacity and knowledge to adapt successfully. Those societies may face increasing asymmetries between demand and supply of the means of subsistence and an associated increased risk of violent conflicts.

In the last decade, possible links between climate change and conflict have gained considerable attention. Much of the debate over the security implications of climate change revolves around whether short-term variability of temperature (e.g. Burke et al. 2009) and precipitation (e.g. Hendrix \& Salehyan 2012) will trigger violent conflicts in Africa. But, no work has been done to quantify how decadal changes in the NAO effect social stability there. It should be noted that the desiccation effect (decreased precipitation) brought about by positive NAO affects both southern Europe and Mediterranean (Dessication
Europe in this study) and northwestern Africa (Scaife et al. 2008, Trouet et al. 2009). Given that the economies of many countries in northwestern Africa are still dependent on agriculture, similar in some ways to pre-industrial Europe, the possible impact brought by decadal NAO variability upon violent conflicts in northwestern Africa should be systematically investigated.

Acknowledgements. We acknowledge the research grant provided by the HKU Seed Funding Programme for Basic Research for the project entitled, 'Revealing the Long-term Dynamics of Drought: The Reconstruction of Drought History in Northwestern China over the Past Millennium' (201109159014) and by the Research Grants Council of The Government of the Hong Kong Special Administrative Region of the People's Republic of China for the projects entitled 'Climate Change and War-Peace Cycles in Eurasia in Recent Human History' (HKU7055/08H) and 'The Causal Mechanism of Drought in Northwestern China over the Past Millennium' (HKU758712H). We thank Prof. Nils Chr. Stenseth and the referees for their valuable comments on the manuscript.

\section{LITERATURE CITED}

Brázdil R, Pfister C, Wanner H, Storch HV, Luterbacher J (2005) Historical climatology in Europe-the state of the art. Clim Change 70:363-430

Brecke P (1999) Violent conflicts 1400 AD to the present in different regions of the world. 1999 Meeting of the Peace Science Society (International), Ann Arbor, MI. www. inta.gatech.edu/peter/PSS99_paper.html

Buhaug H (2010) Climate not to blame for African civil wars. Proc Natl Acad Sci USA 107:16477-16482

Büntgen U, Tegel W, Nicolussi K, McCormick M and others (2011) 2500 years of European climate variability and human susceptibility. Science 331:578-582

Burke MB, Miguel E, Satyanath S, Dykema JA, Lobell DB (2009) Warming increases the risk of civil war in Africa. Proc Natl Acad Sci USA 106:20670-20674

> Cook ER, D'Arrigo RD, Mann ME (2002) A well-verified, multiproxy reconstruction of the winter North Atlantic Oscillation Index since AD 1400. J Clim 15:1754-1764

> Cullen HM, DeMenocal PB (2000) North Atlantic influence on Tigris-Euphrates streamflow. Int $\mathrm{J}$ Climatol 20: 853-863

Eckhardt W (1990) Civilizations, empires, and wars. J Peace Res 27:9-24

> Eckhardt W (1991) War-related deaths since 3000 BC. Secur Dialogue 22:437-443

> Glueck MF, Stockton CW (2001) Reconstruction of the North Atlantic Oscillation, 1429-1983. Int J Climatol 21: 1453-1465

> Hendrix CS, Salehyan I (2012) Climate change, rainfall, and social conflict in Africa. J Peace Res 49:35-50

> Hsiang SM, Meng KC, Cane MA (2011) Civil conflicts are associated with the global climate. Nature 476:438-441

Huntington E (1907) The pulse of Asia: a journey in Central Asia illustrating the geographic basis of history. Houghton Mifflin, London

> Hurrell JW (1995) Decadal trends in the North Atlantic 
Oscillation: regional temperatures and precipitation. Science 269:676-679

Hurrell JW, Van Loon H (1997) Decadal variations in climate associated with the North Atlantic Oscillation. Clim Change 36:301-326

Kohn GC (1999) Dictionary of wars. Facts On File, New York, NY

Luard E (1986) War in international society: a study in international sociology. Tauris, London

Maslow AH (1970) Motivation and personality. Harper \& Row, New York, NY

Pfister C (2007) Climatic extremes, recurrent crises and witch hunts: strategies of European societies in coping with exogenous shocks in the late sixteenth and early seventeenth centuries. Mediev Hist J 10:33-73

Pinker S (2011) The better angels of our nature: why violence has declined. Viking, New York, NY

Scaife AA, Folland CK, Alexander LV, Moberg A, Knight JR (2008) European climate extremes and the North Atlantic Oscillation. J Clim 21:72-83

Sorokin PA (1937) Social and cultural dynamics, Vol 3. Fluctuations of social relationships, war, and revolution. American Book Company, New York, NY

Taagepera R (1979) Size and duration of empires: growthdecline curves, 600 BC to 600 AD. Soc Sci Hist 3:115-138

Taagepera R (1997) Expansion and contraction patterns of large polities: context for Russia. Int Stud Q 41:475-504

Tol RSJ, Wagner S (2010) Climate change and violent conflict in Europe over the last millennium. Clim Change 99:65-79

Trigo RM, Osborn TJ, Corte-Real JM (2002) The North

Editorial responsibility: Nils Chr. Stenseth,

Oslo, Norway
Atlantic Oscillation influence on Europe: climate impacts and associated physical mechanisms. Clim Res 20: $9-17$

Trouet V, Esper J, Graham NE, Baker A, Scourse JD, Frank DC (2009) Persistent positive North Atlantic Oscillation mode dominated the Medieval climate anomaly. Science 324:78-80

Wang G, Dolman AJ, Alessandri A (2011) A summer climate regime over Europe modulated by the North Atlantic Oscillation. Hydrol Earth Syst Sci 15:57-64

Zhang Z, Tian H, Cazelles B, Kausrud KL, Bräuning A, Guo F, Stenseth NC (2010) Periodic climate cooling enhanced natural disasters and wars in China during AD 10-1900. Proc R Soc Lond, B 277:3745-3753

> Zhang DD, Jim CY, Lin CS, He YQ, Wang JJ, Lee HF (2006) Climatic change, wars and dynastic cycles in China over the last millennium. Clim Change 76:459-477

Zhang DD, Lee HF, Wang C, Li B, Pei Q, Zhang J, An Y (2011) The causality analysis of climate change and large-scale human crisis. Proc Natl Acad Sci USA 108: 17296-17301

Zhang DD, Jim CY, Lin CS, He YQ, Lee HF (2005) Climate change, social unrest and dynastic transition in ancient China. Chin Sci Bull 50:137-144

Zhang DD, Brecke P, Lee HF, He YQ, Zhang J (2007a) Global climate change, war, and population decline in recent human history. Proc Natl Acad Sci USA 104: 19214-19219

Zhang DD, Zhang J, Lee HF, He YQ (2007b) Climate change and war frequency in Eastern China over the last millennium. Hum Ecol 35:403-414

Submitted: September 25, 2011; Accepted: July 31, 2012 Proofs received from author(s): December 31, 2012 